\title{
TINGKAT PENGETAHUAN PASANGAN USIA SUBUR BERHUBUNGAN DENGAN PENGGUNAAN ALAT KONTRASEPSI SENGGAMA TERPUTUS
}

\author{
Lia Mulyanti ${ }^{*}$, S.A.S Prihatin Fuji Lestari ${ }^{2}$ \\ 1,2Program Studi S1 Kebidanan Dan Profesi Bidan Universitas Muhammadiyah Semarang Jawa Tengah \\ *Korespondensi Email: lia.mulyanti@unimus.ac.id
}

\section{LEVEL OF KNOWLEDGE OF RELATED FERTILE AGE COUPLES WITH THE USE OF DISCONNECTED CONTRACEPTION TOOLS}

Background: This increase in population growth rate is due to the high birt rate. The government's efforts to reduce the high birth rate are through the National Family Planning Program. One of the factors affecting the increase in birth rates is the lack of use of contraceptive methods. Tembalang Subdistrict has 12 Kelurahan with a total of 29,756 Fertile Age Couples (PUS), and the number of Fertile Age Couples (PUS) who are not Family Planning (KB) participants as many as 7,905 people. The subdistric that do not use family planning (KB) the most are located in Kelurahan Meteseh with 1669 PUS from the number of fertile age couples (PUS), which are 4299 people (38.8\%). Of the 4299 people who used the Intra Uterine Device (IUD), 272 were, the Operative Method for Men (MOP) was 14, the Female Operative Method (MOW) was 230, the Implant was 167 people, the injection was 1312, the Pill was 439, and the Condom was 196 people.

Purpose: To determine the relationship between the level of knowledge of couples of childbearing age and the use of intercourse contraceptives.

Methods: descriptive study with cross sectional research design. By using a total sample of 39 couples of childbearing age in the village of Meteseh.

Results: Majority of respondents had less knowledge 53.8\% (21 PUS) and good knowledge $46.2 \%$ (18 PUS) while the use of contraceptive devices at PUS found that the majority of respondents were irregular in the use of interrupted intercourse $53.8 \%$ and the frequency $46.2 \%$ of regular intercourse use.

Conclusion: There is a relationship between the level of knowledge and the use of the intercourse contraceptive method.

Suggestion For the community, especially fertile age couples, should increase knowledge about contraception, interrupted intercourse by seeking information through health workers or through the media.

Keywords: Knowledge, Fertile Age Couple, Contraception

\section{ABSTRAK}

Latar Belakang: Kenaikan laju pertumbuhan penduduk disebabkan karena angka kelahiran yang masih tinggi. Upaya pemerintah untuk menurunkan angka kelahiran yang masih tinggi tersebut melalui Program Keluarga Berencana Nasional. Salah satu faktor yang mempengaruhi meningkatnya angka kelahiran yaitu masih kurangnya penggunaan metode kontrasepsi. Di Kecamatan Tembalang mempunyai 12 Kelurahan dengan jumlah 29.756 Pasangan Usia Subur (PUS), dan jumlah Pasangan Usia Subur (PUS) bukan peserta Keluarga Berencana (KB) sebanyak 7.905 jiwa. Kelurahan yang paling banyak tidak menggunakan Keluarga Berencana (KB) yaitu terletak di Kelurahan Meteseh sebesar 1669 PUS dari jumlah Pasangan Usia Subur (PUS) yang ada 4299 jiwa (38,8\%). Dari 4299 jiwa yang mengunakan Intra Uterine Device (IUD) sebesar 272 jiwa, Metode Operatif Pria (MOP) 14 jiwa, Metode Operatif Wanita (MOW) 230 jiwa, Implant 167 jiwa, Suntikan 1312 jiwa, Pil 439 jiwa, dan Kondom 196 jiwa.

Tujuan: Untuk mengetahui hubungan tingkat pengetahuan pasangan usia subur dengan penggunaan alat kontrasepsi senggama terputus.

Metode: Penelitian diskiptif dengan rancangan Penelitian cross sectional. Dengan menggunakan total sampel yaitu 39 pasangan usia subur di kelurahan Meteseh.

Hasil: Mayorita responden memiliki pengetahuan kurang 53,8\% (21 PUS) dan yang berpengetahuan baik 46,2\% (18 PUS) seangkan penggunaan alat kontasapesi pada PUS didapatkan bahwa mayoritas responden tidak teratur dalam penggunaan senggama terputus $53,8 \%$ dan frekuensi yang teratur dalam emnggunakan senggama terputus $46,2 \%$. Simpulan: Ada hubungan antara tingkat pengetahuan dengan penggunaan metode kontrasepsi senggama terputus 


\section{JKM (Jurnal Kebidanan Malahayati),Vol 7,No.2.April 2021, ISSN (Print) 2476-8944 ISSN (Online) 2579-762X, Hal 354-358}

Saran bagi masyarakat khususnya pasangan usia subur hendaknya meningkatkan pengetahuan tentang kontrasepsi senggama terputus dengan mencari informasi melalui tenaga kesehatan atau melalui media

Kata Kunci : Pengetahuan, Pasangan Usia Subur, Kontrasepsi

\section{PENDAHULUAN}

Berdasarkan data kependudukan semester I 2020 jumlah total penduduk Indonesia per 30 juni sebanyak 268.583.016 jiwa. Dilansir dari pers Dukcapil Kemendagri, dari jumlah itu sebanyak 135.821.768 orang adalah penduduk laki-laki. Jumlah ini mengalami kenaikan sebesar 0,71\% dibandingkan 2019. Dari data yang smaa tercatat 132.761.248 penduduk perempuan. Jumlah ini juga mengalami kenaikan 0,82\% dibandingkan 2019 (Kompas, 2020).

Kenaikan laju pertumbuhan penduduk ini disebabkan karena angka kelahiran yang masih tinggi. Upaya pemerintah untuk menurunkan angka kelahiran yang masih tinggi tersebut melalui Program Keluarga Berencana Nasional. Salah satu faktor yang mempengaruhi meningkatnya angka kelahiran yaitu masih kurangnya penggunaan metode kontrasepsi. (Aziza, 2019).

Masih cukup tingginya laju pertumbuhan penduduk disebabkan masih lebih tingginya tingkat kelahiran dibanding tingkat kematian. Pertumbuhan penduduk yang tinggi nmenyebabkan hasil-hasil pembangunan kurang bisa dirasakan masyarakat. Oleh karena itu upaya langsung untuk menurunkan tingkat kelahiran masih perlu ditingkatkan (Anggaraini, 2012).

Peserta Keluarga Berencana Baru secara nasional di Indonesia pada tahun 2013 sebanyak 5.547 .543 peserta, meliputi $348.134 \quad(7,85 \%)$ peserta IUD (intra uterin device), 85.137 (1,53\%) peserta MOW (Metode Operasi Wanita), 475.463 (8,57\%) peserta Implant, $2.748 .777 \quad(49,55 \%)$ peserta Suntikan, 1.458 .464 peserta Pil 26,29\%, 9.375(0,025\%) peserta MOP (Metode Operasi Pria), dan $330.303(5,95 \%)$ peserta Kondom (BKKBN, 2013)

Menurut Purwasari (2019) terdapat berbagai macam metode kontrasepsi yang sering digunakan oleh masyarakat seperti Metode Operatif Pria (MOP), Metode Operatif Wanita (MOW), Intra Uterine Device (IUD), Implant, Suntik, Pil, dan Kondom. Tetapi sampai saat ini masyarakat masih banyak juga yang menggunakan Metode Kontrasepsi yang paling sederhana yaitu Senggama terputus atau coitus interuptus. Ada beberapa faktor yang mempengaruhi akseptor dalam memilih metode kontrasepsi antara lain faktor pasangan, faktor kesehatan dari Pasangan
Usia Subur (PUS) itu sendiri, dan faktor metode kontrasepsi yang ingin digunakan. Program KB di Indonesia sebelum dan sesudah ICPD-1994 mengalami perubahan yang nyata pada kurun 70 an sampai 90-an awal. Pelayanan Keluarga Berencana sangat menekankan pada aspek Demografis, yaitu pengendalian angka kelahiran (BKKBN, 2014)

Hasil penelitian sebelumnya oleh Sugiarti (2012) menunjukkan gambaran kontrasepsi yang digunakan adalah non kontrasepsi jangka panjang sebanyak 58,5\% dan metode kontrasepsi jangka panjang sebanyak $41,5 \%$, dengan kesimpulan ada hubungan antara tingkat pengetahuan dengan pemilihan jenis kontrasepsi pada Wanita Usia Subur (WUS).

Rendahnya keikutsertaan pria dalam penggunaan KB disebabkan karena sasaran KB Sebagian besar perempuan dan laki-laki kadang dipandang sebelah mata sehingga penyampaian informasi tidak banyak terkait kontrasepsi. Banyaknya factor pemicu dari rendahnya MOP juga dikarenakan perilaku individu yang berupa respon atau reaksi sangat bergantung dan meliputi Pendidikan terakhir, tingkat emosional dan suku (Irawan et al., 2013)

Peran keluarga khususnya istri memiliki peran yang sangat tinggi untuk memotivasi suami. Dukungan keluarga dapat berupa dukungan social internal, dukungan istri, anak, saudara kandung, sampai pada orang tua (Ali 2010)

Menurut Sugiharti (2011) pengetahuan ibu yang baik belum tentu akan mendapatkan respon yang baik pula dari suami karena suatu keadaan dan alasan tertentu sehingga suami tidak mendukung istri dalam menggunakan $\mathrm{KB}$.

Kelurahan Meteseh (2014) mengatakan di Kelurahan Meteseh sebesar 1669 PUS dari jumlah Pasangan Usia Subur (PUS) yang ada 4299 jiwa $(38,8 \%)$ sedangkan di 3 RW yaitu RW XIV dengan jumlah PUS 240 orang yang menggunakan senggama terputus 8 orang, RW XXIII dengan jumlah PUS 75 orang yang menggunakan senggama terputus 10 orang, dan RW XXIV dengan jumlah PUS 134 orang yang menggunakan senggama terputus 21 orang (Kelurahan Meteseh, 2014). 


\section{METODE PENELITIAN}

Penelitian ini merupakan penelitian diskiptif dan rancangan yang digunakan pada penelitian ini yaitu cross sectional. dengan teknik sampling yaitu teknik sampling kuota. Populasi penelitian ini adalah semua PUS yang menggunakan metode kontasepsi senggama terputus. Sampel dalam penelitian ini menggunakan seluruh populasi yaitu sebesar 39 PUS.

\section{HASIL DAN PEMBAHASAN}

Analisa Univariat

Berdasarkan dari Tabel 1 Distribusi responden berdasarkan umur yaitu usia minimum suami yaitu pada umur 26 tahun sedangkan umur maksimum dari suami yaitu 49 tahun dengan ratarata umur suami yaitu 34.46 tahun, sedangkan standar deviasi umur suami yaitu 5.433 . Dari tabel tersebut juga dapat dilihat umur minimum istri yaitu 22 tahun, umur maksimum istri yaitu 43 tahun dengan rata-rata umur istri dari 39 responden yaitu 31.59 tahun, sedangkan standar deviasinya yaitu 4.523.

Sedangkan distribusi responden berdasarkan pendidikan didapatkan bahwa mayoritas pendidikan suami yaitu pendidikan tinggi dengan jumlah 35 PUS $(89,7 \%)$. Untuk distribusi mayoritas pendidikan istri yaitu pendidikan tinggi sebanyak 29 PUS $(73,4 \%)$,

Tabel 1.

Karateristik Reponden

\begin{tabular}{clcc}
\hline & \multicolumn{1}{c}{ Kategori } & Frekuensi & Persentase \\
\hline Umur & & & \\
suami & Remaja awal (12-16 tahun) & 0 & $0 \%$ \\
& Remaja akhir (17-25 tahun) & 0 & $0 \%$ \\
& Dewasa awal (26-35 tahun) & 23 & $59,0 \%$ \\
& Dewasa akhir (36-45 tahun) & 14 & $35,9 \%$ \\
\multirow{5}{*}{ Istri } & Lansia awal (46-55 tahun) & 2 & $5,1 \%$ \\
& Remaja awal (12-16 tahun) & 0 & $0 \%$ \\
& Remaja akhir (17-25 tahun) & 2 & $5,1 \%$ \\
& Dewasa awal (26-35 tahun) & 31 & $79,5 \%$ \\
& Dewasa akhir (36-45 tahun) & 6 & $15,4 \%$ \\
Pendidikan & & 0 & $0 \%$ \\
Suami & Lansia awal (46-55 tahun) & & \\
& & 0 & $0 \%$ \\
& Pendidikan Dasar & 4 & $10,3 \%$ \\
& Pendidikan Menengah & 35 & $89.7 \%$ \\
& Pendidikan Tinggi & 0 & $0 \%$ \\
& Pendidikan Dasar & 10 & $25,6 \%$ \\
& Pendidikan Menengah & 29 & $73,4 \%$ \\
\hline
\end{tabular}

Tabel 2.

Tingkat Pengetahuan Responden

\begin{tabular}{|c|c|c|}
\hline Tingkat Pengetahuan & Frekuensi (n) & Persentase (\%) \\
\hline Baik & 18 & 46,2 \\
\hline Kurang & 21 & 53,8 \\
\hline Total & 39 & 100 \\
\hline
\end{tabular}

Berdasarkan tabel 2 diketahui bahwa distribusi responden berdasarkan tingkat pengetahuan, diketahui bahwa mayoritas memiliki

pengetahuan kurang 21 PUS $(53,8 \%)$ dan berpengetahuan baik yaitu 18 orang $(46,2 \%)$

Tabel 3.

Penggunaan Senggama Terputus 
JKM (Jurnal Kebidanan Malahayati),Vol 7,No.2.April 2021,

ISSN (Print) 2476-8944 ISSN (Online) 2579-762X, Hal 354-358

\begin{tabular}{lcc}
\hline \multicolumn{1}{c}{ Penggunaan Senggama } & Frekuensi $(\mathbf{n})$ & Persentase (\%) \\
\hline Teratur & 18 & 46,2 \\
Tidak teratur & 21 & 53,8 \\
\hline \multicolumn{1}{c}{ Total } & 39 & 100 \\
\hline
\end{tabular}

Berdasarkan tabel 3 distribusi frekuensi responden berdasarkan penggunaan kontrasepsi senggama terputus yaitu mayoritas responden tidak teratur dalam menggunaan senggama terputus yaitu sebanyak 21 orang $(53,8 \%)$, dan frekuensi yang teratur adalah teratur yaitu sebanyak 18 orang $(46,2 \%)$

\section{Analisa Bivariat}

Dari Tabel 4 Pasangan Usia Subur yang mempunyai pengetahuan baik dan penggunaan kontrasepsi senggama terputus secara teratur yaitu 12 PUS $(66,7 \%)$ sedangkan pasangan usia subur yang mempunyai pengetahuan baik dan penggunaan kontrasepsi senggama terputus secara tidak teratur adalah 6 PUS (33,3\%) dengan total PUS berpengetahuan baik 18 orang. Pasangan usia subur yang mempunyai pengetahuan kurang dan penggunaan kontrasepsi senggama terputus secara teratur sebanyak 6 PUS $(28,6 \%)$, sedangan pasangan usia subur yang mempunyai pengetahuan kurang dan penggunaan senggama terputus secara tidak teratur sebanyak 15 PUS $(71,4 \%)$ dengan total PUS berpengetahuan kurang 21 PUS.

Tabel 4.

Distribusi Responden Berdasarkan Hubungan antara Tingkat Pengetahuan dengan Penggunaan Kontrasepsi Senggama Terputus

\begin{tabular}{|c|c|c|c|c|c|c|}
\hline \multirow[b]{2}{*}{ Variabel } & \multicolumn{4}{|c|}{ Penggunaan senggama terputus } & \multirow[b]{2}{*}{ Jumlah } & \multirow[b]{2}{*}{$\%$} \\
\hline & Teratur & $\%$ & $\begin{array}{l}\text { Tidak } \\
\text { teratur }\end{array}$ & $\%$ & & \\
\hline Pengetahuan baik & 12 & $66,7 \%$ & 6 & $28,6 \%$ & 18 & $46,2 \%$ \\
\hline Pengetahuan kurang & 6 & $28,6 \%$ & 15 & $71,4 \%$ & 21 & $53,8 \%$ \\
\hline Total & 18 & $46,2 \%$ & 21 & $53,8 \%$ & 39 & $100 \%$ \\
\hline
\end{tabular}

\section{PEMBAHASAN}

Uniivariat

Distribusi responden berdasarkan umur yaitu usia minimum suami yaitu pada umur 26 tahun sedangkan umur maksimum dari suami yaitu 49 tahun sedangkan umur minimum istri yaitu 22 tahun, umur maksimum istri yaitu 43 tahun

Menurut Kusumaningrum (2009) usia tersebut adalah umur matang dalam reproduksi wanita, umur merupakan salah satu faktor yang mempengaruhi tingkat pengetahuan dan juga dapat mempengaruhi faktor dalam memilih metode kontrasepsi., hal ini didasari pada pengalaman hidup dan banyaknya informasi yang didapat.

Menurut Mubarak (2011) umur dapat mempengaruhi aspek fisik dan psikologis.Perubahan fisik terjadi karena pematangan fungsi organ tubuh dan pada aspek psikologis taraf berfikir semakin dewasa.Pada golongan umur 26-35 tahun yaitu masa dewasa awal, dalam hal ini aspek psikologis taraf berfikir pada umur tersebut sudahsemakin dewasa

Berdasarkan tabel 2 tentang distribusi responden berdasarkan pendidikan didapatkan bahwa mayoritas pendidikan suami yaitu pendidikan tinggi dengan jumlah 35 PUS (89,7\%). Untuk distribusi mayoritas pendidikan istri yaitu pendidikan tinggi sebanyak 29 PUS $(73,4 \%)$, Menurut Mubarak (2011) pendidikan ialah bimbingan yang diberikankepada orang lain tentang suatu hal, semakin tinggi tingkat pendidikan maka semakin banyak pula informasi yang didapat. Sedangkan menurut Notoatmodjo (2010) tingkat pendidikan ditujukan untung mengubah kesadaran, memberikan atau meningkatkan pengetahuan masyarakat tentang pemeliharaan dan peningkatan kesehatan baik bagi dirinya sendiri, keluarga, maupun masyarakatnya. Pendidikan juga memberikan pengertian-pengertian tentang tradisi yang ada dimasyarakat, kepercayaan masyarakat baik yang merugiakan maupun yang menguntungkan masyarakat. Dalam hal ini menunjukkan bahwa sebagian responden memiliki pendidikan yang cukup, tapi karena pendidikan kesehatan yang didapat oleh responden kurang sehingga hal tersebut berdampak pada informasi dan pengetahuan yang baik mengenai KB. 


\section{JKM (Jurnal Kebidanan Malahayati),Vol 7,No.2.April 2021, ISSN (Print) 2476-8944 ISSN (Online) 2579-762X, Hal 354-358}

Faktor yang mempengaruhi responden mempunyai pengetahuan kurang tentang kontrasepsi senggama teputus karena pasangan tersebut tidak pernah diberi pendidikan kesehatan tentang kontrasepsi senggama terputus dan belum pernah mendapat informasi dari media massa. Hal ini sesuai dengan teori pendapat Mubarak (2011) yang menyatakan pengetahuan adalah hasil tahu seseorang terhadap sesuatu melalui sistem penginderaan yang dimilikinya seperti mata, hidup, telinga, dll. Informasi yang didapat dari berbagai sumber akan mempengaruhi tingkat pengetahuan seseorang. Jika seseorang banyak memperoleh informasi maka ia akan cenderung mempunyai pengetahuan yang luas. Pengetahuan ini bisa didapat dari berbagai sumber yang akan menambah informasi.Yang mempengaruhi pengetahuan antara lain pendidikan, pengalaman, dan informasi. Pendidikan berarti bimbingan yang diberikan terhadap orang lain untuk mencapai tujuan tertentu, sedangkan informasi berguna untuk menambah pengetahuan tentang suatu objek. Keduanya mempunyai peran penting dalam pengetahuan seseorang.

Selain dukungan dari keluarga terdapat dukungan yang tidak kalah pentingnya lagi dan berhubungan untuk meningkatkan penggunaan MOP yaitu dukungan dari tenaga kesehatan. Hasil penelitian sebelumnya di Surakarta menemukan hasil yang sama bahwa terdapat hubungan dukungan tenaga kesehatan dengan peningkatan penggunaan MOP pada suami pasangan usia subur (Muyassaroh et al., 2018).

frekuensi responden berdasarkan penggunaan kontrasepsi senggama terputus yaitu mayoritas responden tidak teratur dalam menggunaan senggama terputus yaitu sebanyak 21 orang $(53,8 \%)$, dan frekuensi yang teratur adalah teratur yaitu sebanyak 18 orang $(46,2 \%)$.

Menurut Kusumaningrum (2009) dukungan pasangan yaitu cara suami atau istri menunjukkan kasih sayang kepedulian, dan empati kepada pasangannya. Partisipasi PUS dalam menggunakan KB dapat menyangkut pemakaian metode kontrasepsi, tempat mendapat pelayanan, lama pemakaian, efek samping dari penggunaan kontrasepsi, dan siapa yang harus menggunakan kontrasepsi. Menurut keterangan responden suami dan istri saling mendukung antara satu dengan yang lainnya, karena suami tidak mengijinkan menggunakan kontrasepsi lain.

Menurut Mubarak (2011) menyimpulkan bahwa perubahan perilaku tidak selalu melewati 5 tahap yaitu kesadaran,ketertarikan, evaluasi, percobaan, dan adopsi. Apabila penerimaan perilaku baru atau adopsi perilaku didasari oleh pengetahuan, kesadaran dan sikap positif, maka perilaku tersebut akan bersifat langgeng. Sebaliknya apabila perilaku tidak didasari oleh pengetahuan, dan kesadaran maka tidak akan berlangsung lama.

Menurut Proverawati (2010) dan Kusumaningrum (2009).Frekuensi senggama adalah senggama atau hubungan suami istri yang dilakukan dalam besaran waktu misalnya frekuensi senggama dalam 1 minggu. Dalam hal ini rata-rata suami mendukung istri untuk menggunakan kontrasepsi senggama terputus. Mereka tidak teratur melakukan kontrasepsi sengama terputus dikarenakan kebanyakan suami yang bekerja kadang-kadang diluar kota.

Menurut Notoatmodjo (2010) praktik (prafice) kesehatan dapat juga dikatakan perilaku kesehatan (over behavior) setelah seseorang mengebai stimulus atau objek kesehatan, kemudian mengadakan penilaian atau pendapat terhadap apa yang diketahui. Proses selanjutnya diarahkan dan akan melaksanakan atau mempraktikan apa yang diketahui atau disepakati. Suami diharapkan dapat meningkatkan kesadaran dirinya untuk ikut berpartisipasi aktif dalam program KB dengan metode apapun karena kesehatan reproduksi dan urusan KB bukan hanya tanggung jawab istri.(Putri,2014)

Menurut Prihastuti,2009 suami dan pasangan terus meningkatkan motivasi intrinsik,dan bidan atau petugas atau pemberi pelayanan $\mathrm{KB}$ yang lain terus berusaha meningkatkan motivasi suami terhadap KB sehingga akseptor vasektomi meningkat dan taraf kesehatan perempuan meningkat. Jika dilihat dari variabel lainnya yang tidak berhubungan adalah pengetahuan dan sikap. Hal ini berbeda ditemukan pada penelitian sebelumnya di Sumbawa bahwa pengetahuan dan sikap berhubungan dengan perilaku penggunaan MOP pada Pria di Sumbawa (Wardani et al., 2020). Hal ini disebabkan informasi yang diterima dapat meningkatkan pengetahuan suami dan sikap suami yang positif terhadap penggunaan kontrasepsi. Tidak seharusnya wanita saja yang menggunakan kontrasepsi tetapi suami juga ikut andil dalam penjarangan kehamilan. 


\section{Bivariat}

Dari Tabel 5 Pasangan Usia Subur yang mempunyai pengetahuan baik dan penggunaan kontrasepsi senggama terputus secara teratur yaitu 12 PUS $(66,7 \%)$ sedangkan pasangan usia subur yang mempunyai pengetahuan baik dan penggunaan kontrasepsi senggama terputus secara tidak teratur adalah 6 PUS $(33,3 \%)$ dengan total PUS berpengetahuan baik 18 orang. Pasangan usia subur yang mempunyai pengetahuan kurang dan penggunaan kontrasepsi senggama terputus secara teratur sebanyak 6 PUS $(28,6 \%)$, sedangan pasangan usia subur yang mempunyai pengetahuan kurang dan penggunaan senggama terputus secara tidak teratur sebanyak 15 PUS $(71,4 \%)$ dengan total PUS berpengetahuan kurang 21 PUS.

Berdasarkan uji statistic dengan uji ChiSquare dari hasil Asymp.sig (2-sided) diperoleh $\mathrm{P}=$ $0,017(<0.05)$ dengan demikian dapat disimpulkan bahwa ada hubungan antara tingkat pengetahuan dengan penggunaan metode kontrasepsi senggama terputus pada pasangan usia subur.

Hasil uji statistik Chi-Square menunjukkan bahwa tingkat pengetahuan tentang mempunyai hubungan yang berbanding lurus dengan penggunaan senggama terputus yang berarti penggunaan senggama terputus yang teratur didasari oleh tingkat pengetahuan PUS yang baik. Hasil analisa diperoleh ada hubungan antara tingkat pengetahuan dengan penggunaan senggama terputus.

Penelitian mulyanti 2016 . Dukungan PUS terhadap akseptor KB tentang senggama terputus sebagian besar saling mendukung yaitu sebesar 20 orang $(51,3 \%)$, dan tidak mendukung sebanyak 19 PUS $(48,7 \%)$. 2. Penggunaan senggama terputus sebagian besar tidak teratur sebesar 21 (53,8\%), dan responden dengan penggunaan senggama terputus teratur sebanyak 18 PUS $(46,2 \%)$.

Menurut setyani2012 status penggunaan alat kontrasepsi ;pada suami rendah,semakin tinggi tingkat pengetahuan tentang KB pria maka semakin tinggi status penggunaan alat kotrasepsi pada suami. Menurut sulaemang 2015 hasil penelitian menunjukkan bahwa terdapat hadis-hadis tentang kebolehan dan larangan melakukan 'Azl, sebagai salah satu wujud mengatur jarak dan pencegahan kehamilan seorang ibu. Implikasi penelitian ini adalah; (1) Untuk mengetahui hadis-hadis Nabi saw. sebagai dasar melakukan al-'Azl pasangan suami istri; (2) Untuk menghilangkan keraguan tentang hadis-hadis al-'Azl apakah dibolehkan melakukannya atau dilarang; (3) Untuk memahami kandungan hukum hadis tentang al-'Azl; (4) Untuk mengetahui bahwa dari seluruh alat KB yang digunakan, yang paling aman dari segi kesehatan, dan hukum Islam adalah melakukan al-'Azl

Berdasarkan analisis data diatas menyatakan bahwa ada hubungan antara tingkat pengetahuan dengan penggunaan senggama terputus, hal ini menunjukkan bahwa penggunaan senggama terputus yang teratur didasari oleh tingkat pengetahuan PUS yang baik, sebaliknya penggunaan senggama terputus yang tidak teratur didasari pada tingkat pengetahuan yang kurang. Pengandalian peningkatan populasi penduduk khususnya di negara berkembang dapat dilakukan dengan cara menekan jumlah kehamilan melalui metode kontrasepsi. Walaupun jumlah dan variasi kontrasepsi pada wanita lebih banyak, namun perkembangan kontrasepsi pria juga sudah mulai dijadikan alternatif. Hal tersebut disasarkan pada prinsip bahwa kualitas kesehatan keluarga yang baik adalah tanggung jawab dari kedua belah pihak yaitu suami dan istri (Ratri,2020). Sebagian besar istri meminta izin kepada suami saat berKB (> 90\%) dimana penentuan alat KB yang digunakan diputuskan oleh baik suami-istri $(45,5 \%$ vs $54,5 \%)$, kesiapan untuk berkB pada suami (kondom atau vasektomi) masih cukup rendah meskipun telah diberikan penyuluhan dan konseling $(30 \%)$. Terdapat pengaruh penyuluhan dan konseling terhadap pengetahuan tentang KB dimana setelah dilakukanpengetahuan meningkat. Jenis KB dengan persentase subyek yang tidak ada gangguan hubungan seksual selama berKB pada terbayak adalah spiral. Sedangkan yang subyek yang ada gangguan terbanyak ditemukan pada kondom. Jenis KB dengan persentasi penurunan kenikmatan hubungan seksual terbanyak ditemukan pada subyek yang melakukan KB tanpa alat yaitu senggama terputus.(Setiawati,2017)

Menurut Notoatmodjo (2010) sikap adalah cenderung untuk bertindak (praktik). Sikap belum tentu terwujud dalam tindakan, sebab untuk terwujudnya tindakan perlu faktor lain antara lain adanya fasilitas atau sarana dan prasarana. Prilaku diawali dengan adanya pengalaman-pengalaman seseorang serta factor-faktor diluar orang tersebut (lingkungan) baik fisik maupun nonfisik. Kemudian pengalaman dan lingkungan tersebut diketahui, dipersepsikan, diyakini, dan sebagainya sehingga menimbulkan motivasi, niat untuk bertindak, dan akhirnya terjadilah perwujudan niat tersebut yang berupa prilaku. Prilaku dikembangkan menjadi 3 diantranya pengetahuan, pengetahuan yaitu hasil tahu seseorang terhadap sesuatu objek. Pengetahuan termasuk kedalam perilaku internal, dalam hal ini terdapat hubungan antara prilaku 


\section{JKM (Jurnal Kebidanan Malahayati),Vol 7,No.2.April 2021, \\ ISSN (Print) 2476-8944 ISSN (Online) 2579-762X, Hal 354-358}

dengan tingkat pengetahuan seseorang. Yang mempengaruhi pengetahuan antara lain pendidikan, pengalaman, dan informasi. Pendidikan berarti bimbingan yang diberikan terhadap orang lain untuk mencapai tujuan tertentu, sedangkan informasi berguna untuk menambah pengetahuan tentang suatu objek. Keduanya mempunyai peran penting dalam pengetahuan seseorang

\section{SIMPULAN}

Ada hubungan antara tingkat pengetahuan dengan penggunaan metode kontrasepsi senggama terputus

\section{SARAN}

Bagi masyarakat khususnya pasangan usia subur hendaknya meningkatkan pengetahuan tentang kontrasepsi senggama terputus dengan mencari informasi melalui tenaga kesehatan atau melalui media

\section{DAFTAR PUSTAKA}

Ali, H. Z., \& SKM, M. (2010). Pengantar keperawatan keluarga. EGC.

Anggaraini, Y. (2012). Pelayanan Keluarga Berencana. Rohima Press.

Aziza, R. N. (2019). Peran program KB dalam pengendalian pertumbuhan penduduk: Studi kasus di Desa Cinta Kecamatan Karangtengah Kabupaten Garut (Doctoral dissertation, UIN Sunan Gunung Djati Bandung)

BKKBN. (2014). Buku Panduan Praktis Pelayanan Kontrasepsi (3rd ed.). PT Bina Pustaka.

Data Kependudukan. 2020. www.nasional.kompas.com (diakses tanggal 06 Oktober 2020)

Irawan, D., Keloko, A. B., \& Syahrial, E. (2013). Perilaku Suami Terhadap Alat Kontrasepsi Pria (Vasektomi) Di Desa Ujung Pulo Cut Kecamatan Bakongan Timur Kabupaten Aceh Selatan Tahun 2013 (Issue 4).

Kusumaningrum, Radita. 2009. Faktor-Faktor Yang Mempengaruhi Pemilihan Jenis Kontrasepsi Yang Digunakan Pasangan Usia Subur.

Kelurahan Meteseh. 2014. Laporan Statistik Dasar atau Pokok Kelurahan Meteseh Kecamatan Tembalang Kota Semarang Bulan Februari 2014. Semarang: Kelurahan Meteseh

Mubarak, Wahit lqbal. 2011. Promosi Kesehatan untuk Kebidanan. Jakarta: Salemba Medika.
Mulyanti, L., \& Lestari, S. P. F. (2016). Hubungan Dukungan Pasangan Usia Subur dengan Penggunaan Metode Kontrasepsi Senggama Terputus di Kelurahan Meteseh Kecamatan Tembalang Kota Semarang. In PROSIDING SEMINAR NASIONAL \& INTERNASIONAL (Vol. 1, No. 1).

Muyassaroh, Y., Astirin, O. P., \& Hanim, D. (2018). Hubungan Antara Pengetahuan Ibu Tentang Kontrasepsi, Jumlah Anak, Dukungan Suami dan Konseling Tenaga Kesehatan Dengan Pemakaian Metode Kontrasepsi Jangka Panjang di Kabupaten Blora. https://doi.org/10.15900/j.cnki.zylf1995.2018. 02.001

Notoatmodjo, Soekidjo. 2010. IImu Perilaku Kesehatan. Jakarta: Rineka Cipta.

Prihastuti, A. F., \& Nawangsih, U. H. E. (2009). GAMBARAN MOTIVASI SUAMI TERHADAP KB VASEKTOMI DI WILAYAH KERJA PUSKESMAS KALASAN SLEMAN YOGYAKARTA TAHUN 2009 (Doctoral dissertation, Universitas' Aisyiyah Yogyakarta).

Proverawati, dkk. 2010. Panduan Memilih Kontrasepsi. Yogyakarta: Nuha Medika

Purwasari, W. (2019). FAKTOR-FAKTOR YANG MEMPENGARUHI PEMILIHAN METODE KONTRASEPSI PADA PASANGAN USIA SUBUR DI KECAMATAN GUNUNGPATI KOTA SEMARANG TAHUN 2019 SKRIPSI JURUSAN GEOGRAFI FAKULTAS ILMU SOSIAL UNIVERSITAS NEGERI SEMARANG 2019 (Doctoral dissertation, UNNES).

Putri, M. A. S., Hariyadi, S., \& Prihastuty, R. (2014). Motivasi suami mengikuti program $\mathrm{kb}$ dengan metode kontrasepsi mantap (vasektomi). Developmental and Clinical Psychology, 3(1).

Ratri, P. R., \& Andriani, M. (2020). Prospek Kontrasepsi Pria dalam Pengendalian Pertumbuhan Penduduk melalui Pendekatan Molekular. ARTERI: Jurnal IImu Kesehatan, 1(2), 147-153.

Setiawati, D., \& Irmawati, I. (2017). Pengaruh Penyuluhan Dan Konseling Terhadap Peranan Gender Terhadap Pemilihan Metode Kontrasepsi Pasangan Suami-Istri Dan Pengaruhnya Terhadap Tingkat Kepuasan Seksual. Jurnal Kesehatan, 10(2), 41-50. 


\section{Lia Mulyanti, S.A.S Prihatin Fuji Lestari}

Setyani, R. A. (2012). Hubungan antara tingkat pengetahuan tentang $\mathrm{KB}$ pria dengan status penggunaan alat kontrasepsi pada suami.

Sugiarti, Imas. 2012. Faktor Pasangan Yang Mepengaruhi Pemilihan Jenis Kontrasepsi Pada Wanita Usia Subur di Kelurahan Cipari Kota Tasikmalaya. (Journal.unsil.ac.id/jurnal/20121/4101/20121 084101077.pdf, diakses 10 Oktober 2020)

Sugiharti, Sri. 2011. Faktor-Faktor Yang Mempengaruhi Rendahnya Akseptor KB AKBK di Desa Wonolopo RW VI Kecamatan Mijen Kota Semarang.
Sulaemang, L. (2015). Al-'Azl (Senggama Terputus) dalam Perspektif Hadis (Disyarah Secara Tahlili). Al-Izzah: Jurnal Hasil-Hasil Penelitian, 10(2), 130-148.

Wardani, S., Latifah, U., \& Lestari, Y. (2020). Hubungan Tingkat Pengetahuan dengan Penggunaan MOP Untuk Melakukan KB Pria Di Desa Baru Tahan Kecamatan Moyo Utara. Jurnal Kesehatan Dan Sains, 3(2), 34-45. 